\title{
How diverse is the lichenized fungal family Trypetheliaceae (Ascomycota: Dothideomycetes)? A quantitative prediction of global species richness ${ }^{\ddagger}$
}

\author{
André APTROOT, Marcela E. S. CÁCERES, Mark K. JOHNSTON and \\ Robert LÜCKING
}

\begin{abstract}
A quantitative prediction of global species richness in the lichenized family Trypetheliaceae employing a grid method previously used in similar approaches for the family Graphidaceae and the genus Cora (Hygrophoraceae) is provided. 421 currently known taxa were used as a base for the calculation and we predict a total of nearly 800 species, corresponding to an increase of almost $100 \%$. Most of the unrecognized taxa are predicted to occur in the Neotropics, which have the highest known species richness. The Palaeotropics are less diverse. In contrast to Graphidaceae, which are mostly confined to rainforests, Trypetheliaceae show substantial species richness in dry forest and savannah ecosystems, and future collection efforts should take well-preserved areas representing such ecosystems into consideration.
\end{abstract}

Keywords: Amazon, Bailey vegetation map, biodiversity, Caatinga, Polymeridium

Accepted for publication 16 May 2016

\section{Introduction}

The most species-rich lichen communities are found in tropical rainforests and various types of dry forest and climatic and edaphic savannah vegetation, including the Brazilian Cerrado and Caatinga, where they cover the bark and leaves of trees and shrubs from the shady understorey to the exposed canopy (Cornelissen \& ter Steege 1989; Sipman \& Harris 1989; Montfoort \& Ek 1990; Marcelli 1992; Wolf 1993; Biedinger \& Fischer 1996; Komposch \& Hafellner 1999, 2000, 2002, 2003; Lücking 2001，2008;

A. Aptroot: ABL Herbarium, G.v.d.Veenstraat 107, NL-3762 XK Soest, The Netherlands.

M. E. S. Cáceres: Departamento de Biociências, Universidade Federal de Sergipe, CEP: 49500-000, Itabaiana, Sergipe, Brazil.

M. K. Johnston and R. Lücking: Science and Education, The Field Museum, 1400 South Lake Shore Drive, Chicago, Illinois 60605-2496, USA.

R. Lücking (corresponding author): Botanic Garden and Botanical Museum Berlin, Königin-Luise-Straße 6-8, 14195 Berlin, Germany. Email: r.luecking@bgbm.org.

${ }^{\ddagger}$ The original version of this article was published with the incorrect pagination. A notice detailing this has been published and the error rectified in the online PDF and HTML copies.
Nöske \& Sipman 2004; Holz \& Gradstein 2005; Lakatos et al. 2006; Cáceres et al. 2007, 2008). Such communities hold various 'richness' records, from the most species on single leaves (50-82 in Costa Rica and Ecuador; Lücking \& Matzer 2001), to the most species on a single tree (173 in Papua New Guinea; Aptroot 1997), to the most species within a given plot (up to 600 in Costa Rica; Lücking et al. 2011).

While these tropical lichen communities are taxonomically diverse, they are dominated by a few, large families of crustose to microsquamulose taxa: the Gomphillaceae, Graphidaceae, Pilocarpaceae, Porinaceae, Pyrenulaceae, Ramalinaceae, and Trypetheliaceae (Sipman \& Harris 1989; Rivas Plata et al. 2008). Trypetheliaceae is the second most diverse group among corticolous lichens after Graphidaceae, both in number of species and in morphological diversity, and is found abundantly in rainforests, dry forests, and savannahs (Komposch \& Hafellner 1999, 2000, 2002, 2003; Aptroot et al. 2008, 2013a; Aptroot 2009a, b). The phylogenetic position and classification of the family has been revised recently (Del Prado et al. 2006; Nelsen et al. 2009, 2011, 2014; 
Hyde et al. 2013) and a new generic concept was introduced to delimit more natural groups (Aptroot et al. 2013b; Nelsen et al. 2014). With this concept as a framework, nearly 400 species are currently distinguished, including a large number of newly discovered taxa described in recent years and in this issue (Aptroot et al. 2013a; Lima et al. 2013; Córdova-Chávez et al. 2014; Weerakoon \& Aptroot 2014). However, most of the data available on the diversity of this family are from a small number of tropical regions, focusing on Costa Rica, the Guianas, the Brazilian Amazon and north-east region, the Indian subcontinent including Sri Lanka, and Australia (Makhija \& Patwardhan 1988, 1993; Aptroot et al. 2008, 2013a; Aptroot 2009a, b; Singh \& Sinha 2010; Weerakoon \& Aptroot 2014), whereas many other areas are still understudied or not explored at all.

In this paper, we use a quantitative approach that extrapolates from sampling effort to predict the global species richness of Trypetheliaceae. The method has previously been used for Graphidaceae, predicting 1800 undiscovered species worldwide (Lücking et al. 2014a), and for the basidiolichen genera Cora and Corella in the Hygrophoraceae, predicting over 450 species in the Americas (Lücking et al. 2014b). The underlying idea of this approach is to divide the target area into grids and establish a strong correlation between observed species richness and richness predictors, including environmental variables and sampling effort as parameters. The expected species richness per grid can then be predicted by setting sampling effort to the theoretical maximum value per grid and estimating the average grid distribution per species. This simple formula is based on the relation between alpha, beta and gamma diversity first established by Whittaker (1960).

\section{Material and Methods}

With few exceptions, Trypetheliaceae are restricted to (sub-)tropical forest and savannah ecosystems. For this reason, we used the same global grid system as previously implemented for Graphidaceae (Lücking et al. $2014 a$ ), a grid map ranging from $30^{\circ}$ northern to $30^{\circ}$ southern latitude, with grids $15^{\circ}$ longitude by $15^{\circ}$ latitude, corresponding to $c .1600 \mathrm{~km}$ in each direction or c. 2.5 million $\mathrm{km}^{2}$ per grid, about $30 \%$ of the area of Brazil. This resulted in 46 grids covering land areas or archipelagos with known data on (sub-)tropical Trypetheliaceae (Fig. 1; Table 1).

Based on published and unpublished data and after careful taxonomic revision that considers revised genus and species concepts, we assembled a global working checklist of species in Trypetheliaceae relative to the grid map (see Supplementary Material A, available online). In addition to publications in the present issue, works reviewed for this purpose include, but are not restricted to: Trevisan (1861), Müller (1888), Malme (1924), Dodge (1953), Letrouit-Galinou (1957, 1958), Harris (1984, 1991, 1998), Makhija \& Patwardhan (1988, 1993), Aptroot (1991, 2009a, b), McCarthy \& Kantvilas (1993), McCarthy (1995), Komposch \& Hafellner (1999, 2000, 2002, 2003), Aptroot \& Ferraro (2000), Komposch et al. (2002), Lücking et al. (2007), Aptroot et al. (2008, 2013a), Singh \& Sinha (2010), Rout et al. (2012), Lima et al. (2013), CórdovaChávez et al. (2014), and Weerakoon \& Aptroot (2014).

Following Lücking et al. (2014a), we assembled a richness prediction score by taking into account four variables developed as scores for each grid (Table 1): 1) sampling score (i.e. sampling effort per grid), ranging from 0 (unsampled) to 5 (assumed maximum sampling effort); 2) vegetation score (i.e. presence and extent of global vegetation types in each grid), combined with a value corresponding to the observed preferences of Trypetheliaceae relative to each vegetation type; 3 ) remote score, being either 1 or 0.7 , relating to the presence of only small, remote islands (more than $1000 \mathrm{~km}$ from the next continent or large island); and 4) region score, either 2 (Neotropics) or 1 (Palaeotropics), which was based on observations made from the six well-sampled grids (sampling score 4, see below), two in the Neotropics and four in the Palaeotropics. The two neotropical grids yielded 75 species on average (73 and 77), whereas the four palaeotropical grids yielded 42 species on average $(52,31,60,26)$, that is about half as many, which coincides with additional experience by the authors in other grids, either through fieldwork or revising collections (Mexico, Costa Rica, Puerto Rico, Colombia, Venezuela, Guianas, Brazil, Cameroon, Tanzania, Madagascar, Thailand, Australia, New Caledonia). Hence this difference, rather than a sampling bias, suggests an underlying difference in the evolutionary history of Trypetheliaceae in these regions.

The remote score is based on the notion that remote islands have a reduced species richness due to dispersal limitations that may only partly be balanced by endemic radiations. Since currently there are not enough data to elaborate this score in a more detailed fashion, we used the same score of 0.7 for grids 45 and 46 (New Caledonia, Hawaii) as developed for Graphidaceae (Lücking et al. 2014a), whereas all other grids received a score of 1 . The exact determination has very little influence on the overall results, since varying the score for these two grids between $0 \cdot 1$ and 1 changes the overall prediction by less than $1 \%$.

Sampling scores were derived from data obtained from published literature and revisions of herbarium collections, as well as recent fieldwork outlined in the aforementioned 

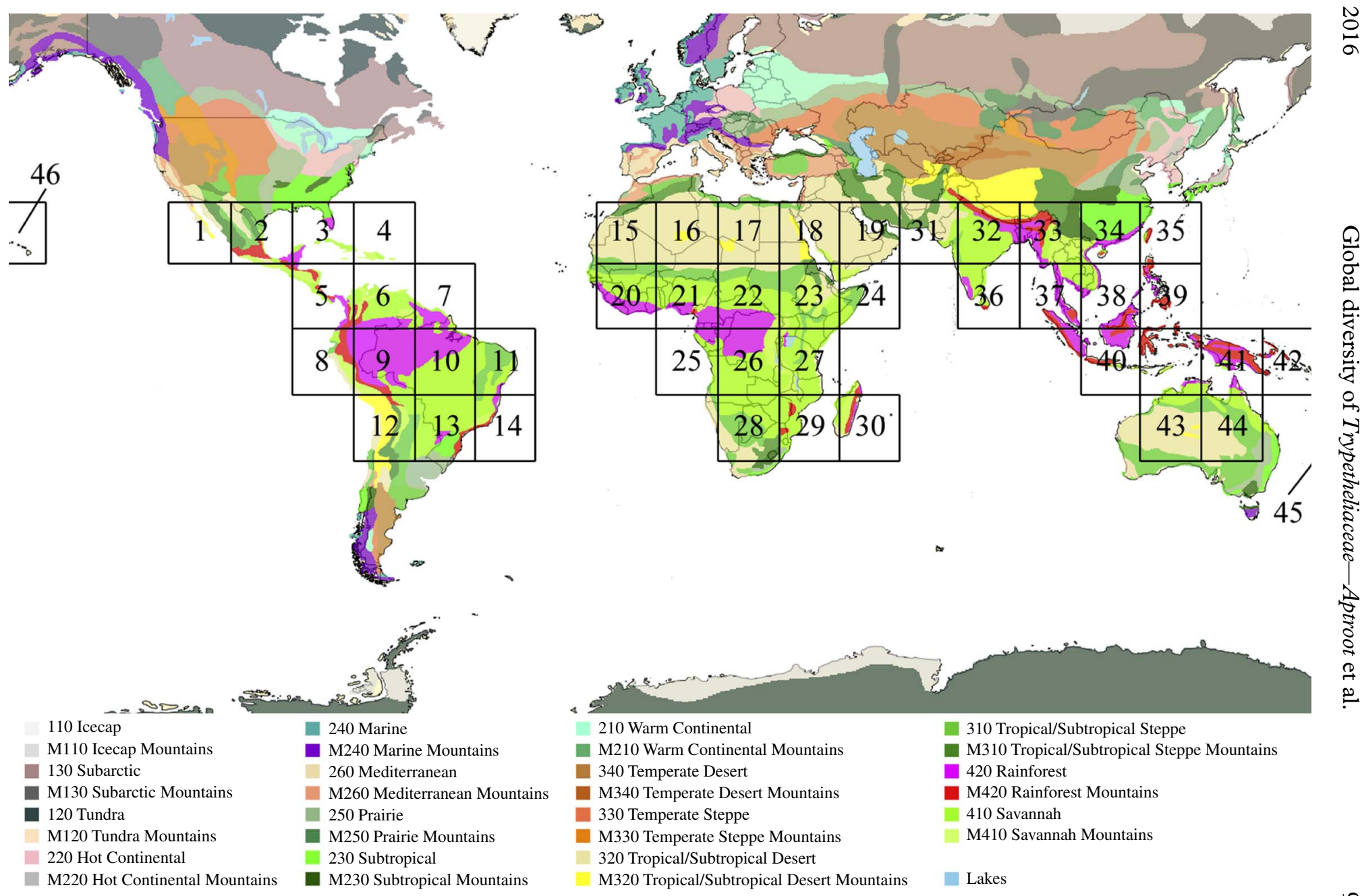

210 Warm Continental 310 Tropical/Subtropical Steppe

M210 Warm Continental Mountains a310 Tropical/Subtropical Steppe Mountains

340 Temperate Desert

420 Rainforest

M340 Temperate Desert Mountains a M420 Rainforest Mountains

- 330 Temperate Steppe

410 Savannah

Mountain

M410 Savannah Mountains

320 Tropical/Subtropical Desert

M320 Tropical/Subtropical Desert Mountains Lakes

FIG. 1. Global $15^{\circ} \times 15^{\circ}$ grid map used for a statistical approach to predicting global species richness for Trypetheliaceae, using as reference an ArcGIS vegetation map derived from Bailey \& Hogg (1986) and Bailey (1989) with ecosystem divisions. The key refers to the 30 divisions plus freshwater lakes. Grid numbers refer to those used in Table 1. 
TABLE 1. Global $15^{\circ} \times 15^{\circ}$ grids (grid numbers correspond to those in Fig. 1) and grid-based scores (see Supplementary Materials $A \mathcal{E} B$, available online). Total score is the product of sampling, vegetation, remote, and region scores; predicted richness is based on setting the sampling score to maximum (5).

\begin{tabular}{|c|c|c|c|c|c|c|c|c|c|}
\hline $\begin{array}{l}\text { Grid } \\
\text { Number }\end{array}$ & $\begin{array}{l}\text { Sampling } \\
\text { Score }\end{array}$ & $\begin{array}{c}\text { Vegetation } \\
\text { Score }\end{array}$ & $\begin{array}{c}\text { Remote } \\
\text { Score }\end{array}$ & $\begin{array}{c}\text { Region } \\
\text { Score }\end{array}$ & $\begin{array}{l}\text { Total } \\
\text { Score }\end{array}$ & $\begin{array}{c}\text { Observed } \\
\text { (Obs) } \\
\text { Richness }\end{array}$ & $\begin{array}{c}\text { Predicted } \\
\text { (Pre) } \\
\text { Richness }\end{array}$ & $\begin{array}{l}\text { Difference } \\
\text { Pre-Obs }\end{array}$ & $\begin{array}{c}\text { Difference } \\
\text { Range }\end{array}$ \\
\hline 1 & 1 & 219 & 1 & 2 & 438 & 2 & 46 & 44 & $(+)$ \\
\hline 2 & 1 & 639 & 1 & 2 & 1278 & 16 & 133 & 117 & $(+++)$ \\
\hline 3 & 4 & 393 & 1 & 2 & 3143 & 72 & 82 & 10 & \\
\hline 4 & 3 & 278 & 1 & 2 & 1668 & 49 & 58 & 9 & \\
\hline 5 & 2 & 850 & 1 & 2 & 3399 & 88 & 176 & 88 & $(++)$ \\
\hline 6 & 3 & 928 & 1 & 2 & 5565 & 106 & 193 & 87 & $(++)$ \\
\hline 7 & 3 & 737 & 1 & 2 & 4420 & 115 & 153 & 38 & $(+)$ \\
\hline 8 & 2 & 509 & 1 & 2 & 2037 & 37 & 106 & 69 & $(++)$ \\
\hline 9 & 3 & 1128 & 1 & 2 & 6765 & 127 & 234 & 107 & $(+++)$ \\
\hline 10 & 1 & 1081 & 1 & 2 & 2161 & 49 & 224 & 175 & $(+++)$ \\
\hline 11 & 4 & 539 & 1 & 2 & 4312 & 77 & 112 & 35 & $(+)$ \\
\hline 12 & 1 & 660 & 1 & 2 & 1320 & 16 & 137 & 121 & $(+++)$ \\
\hline 13 & 1 & 772 & 1 & 2 & 1544 & 43 & 160 & 117 & $(+++)$ \\
\hline 14 & 3 & 509 & 1 & 2 & 3056 & 59 & 106 & 47 & $(+)$ \\
\hline 15 & 2 & 334 & 1 & 1 & 668 & 4 & 35 & 31 & $(+)$ \\
\hline 16 & 0 & 266 & 1 & 1 & 0 & 0 & 28 & 28 & $(+)$ \\
\hline 17 & 0 & 285 & 1 & 1 & 0 & 0 & 30 & 30 & $(+)$ \\
\hline 18 & 0 & 412 & 1 & 1 & 0 & 0 & 43 & 43 & $(+)$ \\
\hline 19 & 1 & 243 & 1 & 1 & 243 & 1 & 25 & 24 & $(+)$ \\
\hline 20 & 1 & 646 & 1 & 1 & 646 & 15 & 67 & 52 & $(++)$ \\
\hline 21 & 1 & 907 & 1 & 1 & 907 & 8 & 94 & 86 & $(++)$ \\
\hline 22 & 0 & 1005 & 1 & 1 & 0 & 1 & 104 & 103 & $(+++)$ \\
\hline 23 & 0 & 656 & 1 & 1 & 0 & 0 & 68 & 68 & $(++)$ \\
\hline 24 & 1 & 194 & 1 & 1 & 194 & 2 & 20 & 18 & \\
\hline 25 & 1 & 459 & 1 & 1 & 459 & 5 & 48 & 43 & $(+)$ \\
\hline 26 & 1 & 1000 & 1 & 1 & 1000 & 7 & 104 & 97 & $(++)$ \\
\hline 27 & 2 & 657 & 1 & 1 & 1314 & 19 & 68 & 49 & $(+)$ \\
\hline 28 & 1 & 602 & 1 & 1 & 602 & 8 & 62 & 54 & $(++)$ \\
\hline 29 & 1 & 549 & 1 & 1 & 549 & 8 & 57 & 49 & $(+)$ \\
\hline 30 & 1 & 397 & 1 & 1 & 397 & 9 & 41 & 32 & $(+)$ \\
\hline 31 & 2 & 411 & 1 & 1 & 823 & 10 & 43 & 33 & $(+)$ \\
\hline 32 & 1 & 773 & 1 & 1 & 773 & 16 & 80 & 64 & $(++)$ \\
\hline 33 & 2 & 678 & 1 & 1 & 1356 & 33 & 70 & 37 & $(+)$ \\
\hline 34 & 2 & 496 & 1 & 1 & 992 & 25 & 51 & 26 & $(+)$ \\
\hline 35 & 2 & 181 & 1 & 1 & 362 & 9 & 19 & 10 & \\
\hline 36 & 4 & 377 & 1 & 1 & 1509 & 52 & 39 & -13 & \\
\hline 37 & 3 & 536 & 1 & 1 & 1609 & 34 & 56 & 22 & \\
\hline 38 & 2 & 681 & 1 & 1 & 1361 & 30 & 71 & 41 & $(+)$ \\
\hline 39 & 4 & 191 & 1 & 1 & 763 & 31 & 20 & -11 & \\
\hline 40 & 3 & 297 & 1 & 1 & 890 & 25 & 31 & 6 & \\
\hline 41 & 4 & 737 & 1 & 1 & 2947 & 60 & 76 & 16 & \\
\hline 42 & 2 & 130 & 1 & 1 & 259 & 8 & 13 & 5 & \\
\hline 43 & 1 & 547 & 1 & 1 & 547 & 5 & 57 & 52 & \\
\hline 44 & 3 & 756 & 1 & 1 & 2268 & 46 & 78 & 32 & $(+)$ \\
\hline 45 & 4 & 193 & 1 & 1 & 541 & 26 & 14 & -12 & \\
\hline 46 & 3 & 181 & 1 & 1 & 380 & 13 & 13 & 0 & \\
\hline
\end{tabular}

Sampling score $=$ sampling effort per grid, ranges from 0 (unsampled) to 5 (assumed maximum sampling effort); vegetation score $=$ presence and extent of global vegetation types in each grid, combined with a value corresponding to the observed preferences of Trypetheliaceae relative to each vegetation type; remote score $=1$ or $0 \cdot 7$ which is presence on only small, remote islands; region score $=2$ (Neotropics) or 1 (Palaeotropics).

$+++=$ differences between predicted and observed numbers of 100 or higher; $++=50-99 ;+=25-49$. See also Fig. 4 (negative differences are the result of the smoothing effect of the regression). 
publications. To determine the score, we counted the number of publications available and their geographical spread within each grid following Lücking et al. (2014a: table 3), along with an evaluation of the underlying taxonomic concept in each case, plus the number and geographical spread of additional, unpublished collections available and revised by us. Since the authors of the present paper were involved in many of the previously published inventories, or else had access to the material, including representative specimens from India, we were able to standardize this information. Possible subjective bias was further limited by the low range of sampling scores allowed (0 to 5). As a result, no grid was considered well sampled (score 5) but six grids were scored as reasonably well sampled (score 4), viz. grids 3, 11, 36, 39, 41, and 45 (Table 1).

For the definition of vegetation types, we followed Lücking et al. (2014a) in using the global vegetation map provided by Bailey \& Hogg (1986) and Bailey (1989), specifically their intermediate division classification level (see Supplementary Material B, available online), since Trypetheliaceae have a world distribution, concentrated in the tropics, similar to that of Graphidaceae. The land area of each division was calculated for each $15^{\circ}$ latitude by $15^{\circ}$ longitude grid cell (Fig. 1) in ArcGIS 10.1 (Spatial Analyst extension). We used a cylindrical equal area projection, which spaced longitudinal lines to form similarly sized rectangular grids, accounting for ocean surface present within grid cells (see Supplementary Material B). Since species richness is logarithmically correlated with area size, we transformed all area values using the exponent 0.25 (see Supplementary Material B), which had previously been identified as a well-fitting model for area-species relationships in Graphidaceae (Lücking et al. 2014a). The Bailey map does not contain data for small islands, so we computed vegetation cover for grids 45 and 46 (New Caledonia, Hawaii) using separate vegetation maps, and also performed corrections for grid 4 (Hispaniola, Puerto Rico, Lesser Antilles) as outlined by Lücking et al. (2014a).
We assigned each vegetation type (Bailey province) a score corresponding to the richness of Trypetheliaceae expected within that vegetation type (Table 2; see Supplementary Material B, available online), using data from quantitative studies that include Trypetheliaceae to rank vegetation types (provinces) according to expected diversity (Cornelissen \& ter Steege 1989; Montfoort \& Ek 1990; Komposch \& Hafellner 1999, 2000, 2002, 2003; Nöske \& Sipman 2004; Holz \& Gradstein 2005; Lakatos et al. 2006; Cáceres et al. 2007, 2008; Aptroot et al. 2008; Rivas Plata et al. 2008). In Graphidaceae, vegetation types that contribute uniquely and substantially to overall species richness are the rainforest and rainforest mountain divisions and the savannah and savannah mountain divisions where they are found mainly in the rainforest canopy (Lücking et al. 2014a). In Trypetheliaceae, the latter two divisions also provide unique taxa, such as in the genera Bogoriella and Polymeridium (Aptroot et al. 2013a). Accordingly, we used a slightly different relative scaling of vegetation scores for Trypetheliaceae, with increased scores for the savannah division (Table 2; see Supplementary Material B, available online).

For each grid, the vegetation score was then computed as the sum of the scores for each Bailey vegetation province present: [Vegetation Score] $=\mathrm{SUM}_{\mathrm{Grid}}$ [pro-

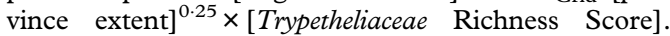
Following Lücking et al. (2014a), sampling, vegetation, remote and region scores were subsequently combined into a total prediction score for each grid by simple multiplication (Table 1).

Variation of observed species richness per grid was compared to variation in total prediction scores by means of linear regression as best fit, using the distribution fitting module in STATISTICA 6.0. Predicted species richness per grid was then computed from the linear model using the maximum sampling score for each grid (5). In addition, predicted global species richness was calculated by dividing the sum total of individual grid species richness by the average number of grids in which a species was estimated to

TABLE 2. Trypetheliaceae species richness scores for different vegetation types (Bailey divisions and provinces). For nomenclature and numbers see Supplementary Material B (available online).

\begin{tabular}{llr}
\hline Division (Provinces) & Division Number (Province number) & Score \\
\hline Rainforest (all provinces) & $420(421,422,424)$ & 10 \\
Savannah (forest provinces) & $410(411,413)$ & 5 \\
Rainforest Mountains (forest provinces) & M420 (unassigned, island grids 45, 46) & 5 \\
Savannah (woodland and grassland provinces) & $410(412,414,415,416)$ & 3 \\
Rainforest Mountains (forest-meadow provinces) & M420 (M421) & 3 \\
Rainforest Mountains (forest-paramo provinces) & M420 (M422, M423) & 1 \\
Tropical/Subtropical Steppe (all provinces) & $310(312,313,314,315)$ & 3 \\
Tropical/Subtropical Desert (all provinces) & $320(321,322,323,324,325,326)$ & 3 \\
Subtropical Mountains (all provinces) & M230 (M231) & 3 \\
Savannah Mountains (all provinces) & M410 (M411, M412, M413) & 3 \\
Subtropical (all provinces) & $230(231)$ & 1 \\
Prairie (all provinces) & $250(254,255)$ & 1 \\
Tropical/Subtropical Steppe Mountains (all provinces) & M310 (M312, M313, M314, M315) & 1 \\
Tropical/Subtropical Desert Mountains (all provinces) & M320 (M321, M322, M323, M324) & 1 \\
Water & & 0
\end{tabular}


be present. To that end, we applied "histogram maximization" as suggested in Lücking et al. (2014b). This method assumes that with further species discoveries, the shape of the frequency histogram remains relatively constant, which allows extrapolation of the number of species added in each category, an approach analogous to the calculation of Chao values (Chao 1984, 1987), since most additional species will appear in the rare categories occurring in only one or two grids. First, we established the frequency histogram of observed species occurrences (i.e. number of species by number of grids in which species are present). Since the maximum number of grids in which the most frequent species was observed was 30 , but the maximum number of possible grids was 46 , we then artificially 'expanded' the $x$-axis by multiplying each grid number by the quotient of $46 / 30$ and using the integer of the result. Thus, the maximum observed grid number 30 became the maximum possible grid number 46 , grid number 15 became grid number 23, and grid number 1 became grid number 2, and so on. To each of these, the observed species number was added, which then allows us to estimate the expected numbers for the 'empty' grids via linear interand extrapolation. To that end, the frequency histogram was log-log transformed to apply linear regression and then back-transformed to compute the estimated number of species per grid category. This resulted in an estimate of the average grid number per species; it also provides an independent test of the global species richness prediction, since the sum over all grids of the regression estimates corresponds to the predicted total richness.

\section{Results}

We assembled a list of 421 taxa of Trypetheliaceae (see Supplementary Material A, available online), which included the 418 species formally accepted in the family (Aptroot \& Lücking 2016) plus three undescribed taxa; 418 of these were present in at least one of the 46 grids, whereas three further species (Aptrootia robusta, Bogoriella collospora, B. striguloides) were exclusively extratropical. Observed species richness per grid ranged from zero in the sub-Saharan African grids 16-18 to a maximum of 106-127 in grids 6, 7, and 9, which correspond to the western Amazon and savannah regions of Colombia, Venezuela, the Guianas, and north-western Brazil (Table 1, Fig. 2). Notably, the highest observed species richness was observed in grids considered moderately well sampled (sampling score 3). In contrast, the best-sampled grids (sampling score 4), grids 3 (Caribbean), 11 (northeastern Brazil), 36 (southern India, Sri Lanka), 39 (Philippines), 41 (Papua New Guinea), and 45 (chiefly New Caledonia) had low to moderate observed species richness, ranging between 26 and 77 taxa.

Linear regression between observed species richness and total prediction score per grid revealed a strong and highly significant relationship (Fig. 3). Setting the sampling score per grid to maximum (5), the predicted species numbers per grid ranged between 28-30 (grids 16 and 17 in sub-Saharan Africa) and 224-234 (grids 9 and 10, corresponding

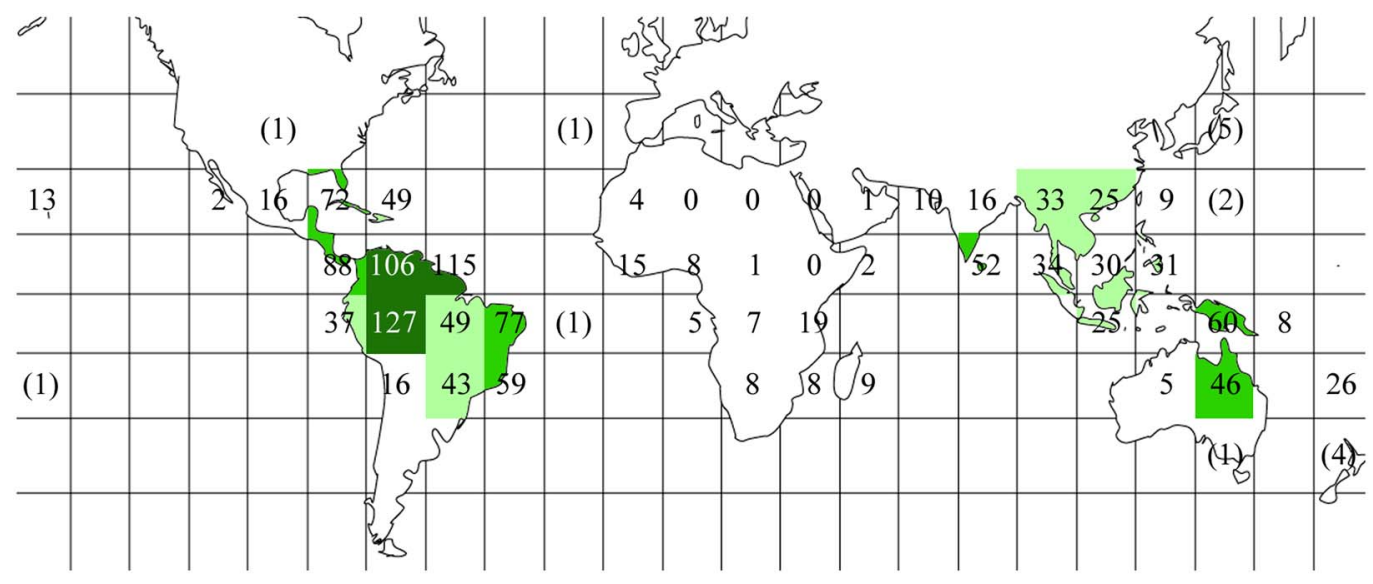

FIG. 2. Global observed species richness heat map for Trypetheliaceae based on data presented in Table 1, using the grid map given in Fig. 1. Different grey tones indicate different numbers of species per grid square: dark grey $\geq 100$; medium grey $=50-99$; light grey $=25-49$; white $<25$. Total species numbers are given, including extra-tropical areas and, in parentheses, additional tropical grids with oceanic islands not taken into account. In colour online. 


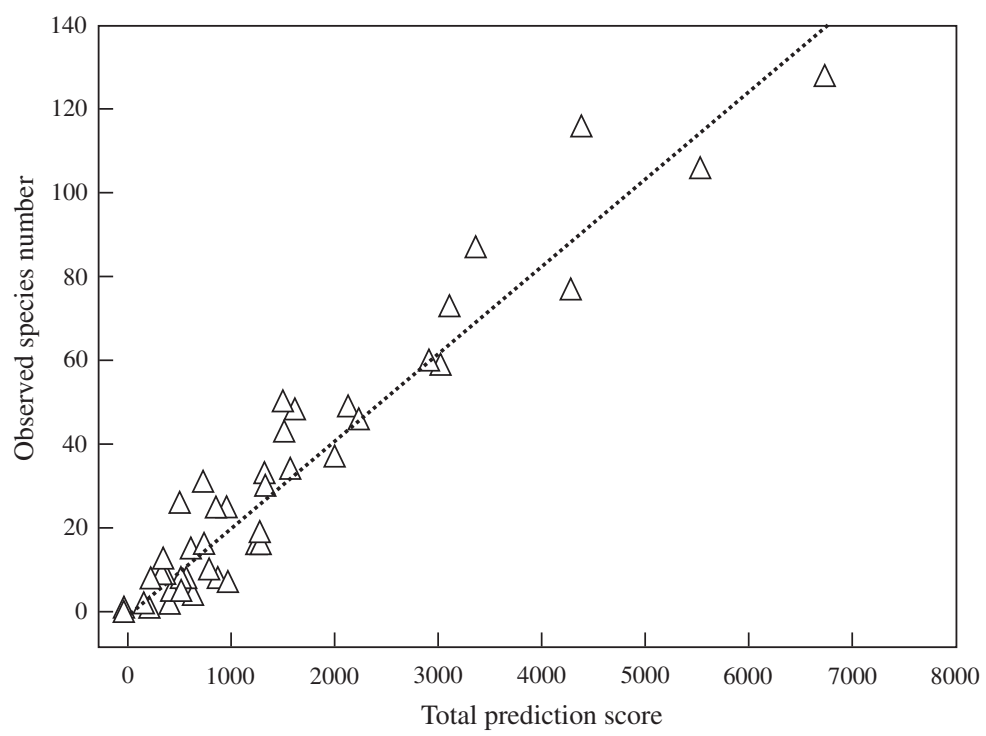

FIG. 3. Linear regression of observed species number per grid on total prediction score derived from sampling, vegetation, remote, and region scores (see Table 1). Observed richness $=0.0208 \times$ total prediction score $\left(r^{2}=0.92, P<0.001\right)$.

chiefly to the western and eastern Amazon) (Fig. 5). The highest per-grid species numbers, with values of 150 taxa or above, were predicted for grids in Central America (grid 5), those around the Amazon region (grids 6, 7, 9, 10 ), and grid 13 representing central and southern Brazil and parts of northern Argentina, corresponding to the Cerrado, Pantanal, and Chaco biomes. Further, high values of above 100 species per grid were predicted for grids 2 (Mexico), 8 (Ecuador, Peru), 11 (north-eastern Brazil), 12 (Bolivia), 14 (southeastern Brazil), and 22 and 26 (central western Africa). All other palaeotropical grids had predictions of $<100$ species each, with the highest numbers for other West African grids, India, Thailand and adjacent areas, Papua New Guinea, and north-eastern Australia.

The observed grid total was 1368 and the predicted grid total 3545 . Observed average grid distribution per species was 3.26 grids. The maximum number of grids occupied by a single species was 30 , observed in one species (Astrothelium porosum), followed by 28 (Pseudopyrenula subnudata, Trypethelium eluteriae), 27 (Astrothelium bicolor, Nigrovothelium tropicum) and 25 grids (Astrothelium megaspermum). In contrast, 202 species, nearly half of the known species, were reported from a single grid only (see Supplementary Material A, available online). Histogram maximization by means of regression between the adjusted, log-transformed, observed frequency values revealed a highly significant relationship (Fig. 4). Through back-transformation, we computed the extrapolated grid total at 3452 and the species total at 800 , resulting in an estimated average grid distribution of 4.43 grids per species, c. $36 \%$ higher than the observed value and corresponding to an area of c. 11 million $\mathrm{km}^{2}$, larger than the size of countries such as Canada, China, the United States, or Brazil. Using the predicted grid total and the estimated average grid distribution per species, the global predicted species richness for Trypetheliaceae was $3545 / 4.43=800$ species. Histogram maximization resulted in an extrapolation of exactly the same number of 800 species, a remarkable coincidence considering that the two methods are partially independent. This prediction almost doubles the number of 421 species currently accepted.

Based on these results, we highlighted regions in which the predicted diversity is 


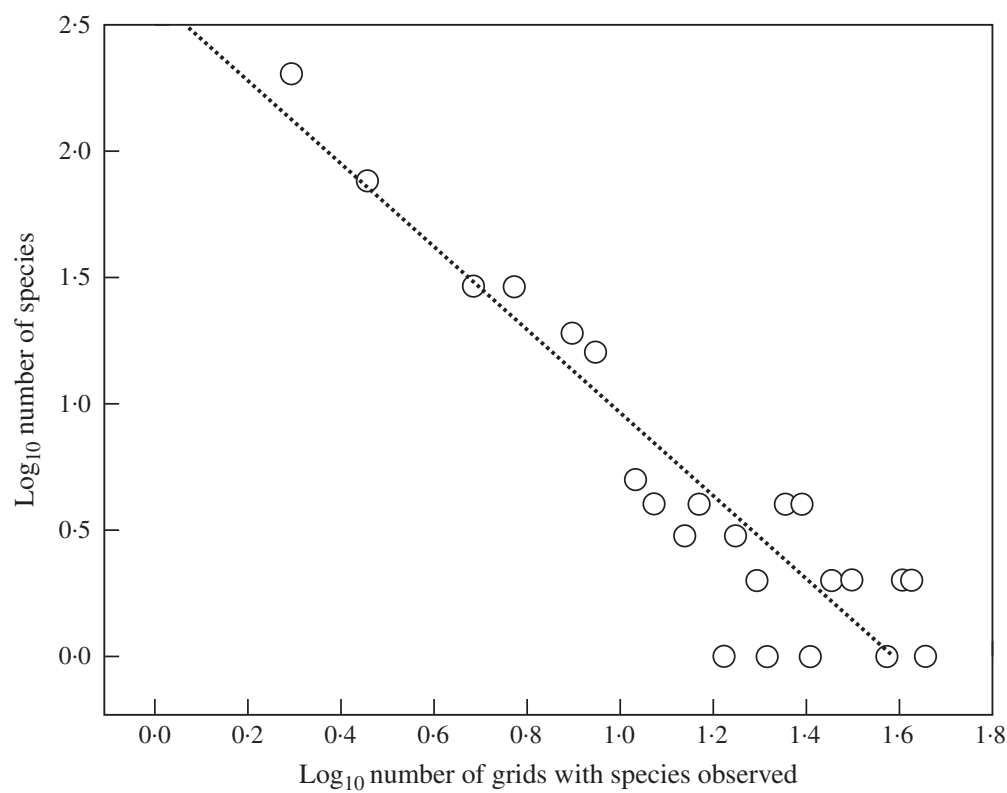

FIG. 4. Linear regression of log-transformed observed species number on log-transformed number of grids in which species were observed. $\log _{10}$ (number of species) $=2.5843-1.6206 \times \log _{10}$ (number of grids) $\left(r^{2}=0.85, P<0.001\right)$.

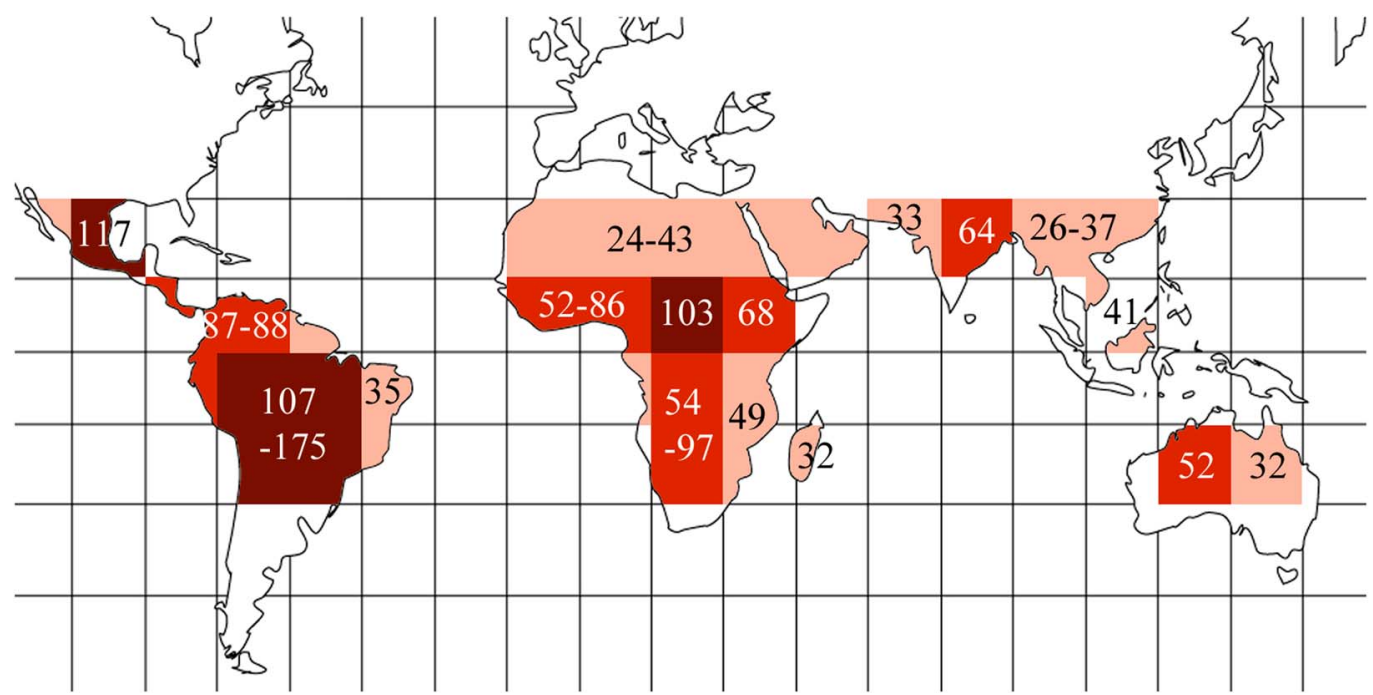

FIG. 5. Global undiscovered species richness heat map for Trypetheliaceae based on data presented in Table 1, using the grid map given in Fig. 1. Different grey tones indicate different numbers of additional species predicted per grid square: dark grey $\geq 100$; medium grey $=50-99$; light grey $=25-49$. Predicted numbers are given for most grids or groups of adjacent grids. In colour online.

likely to be discovered (Table 1, Fig. 5). These are concentrated in the Amazon region and southern Brazil, plus at a lower level the entire
Neotropics, most of tropical Africa including Madagascar, north-eastern India and adjacent regions, and north-eastern Australia. 


\section{Discussion}

Compared to the currently accepted number of 421 species in Trypetheliaceae, our results, based on two partially independent methods, predict that the true number (800) is about twice as high. This prediction appears reasonable, considering that many tropical areas potentially rich in Trypetheliaceae have either not been well studied or not studied at all. The results are proportionally similar to those obtained for Graphidaceae (Lücking et al. $2014 a$ ), in which the number of tropical species was also estimated to be about twice as high (nearly 4000) as the number currently accepted (c. 2100). Since Graphidaceae is considerably larger, however, the impact on the absolute number of expected taxonomic novelties is smaller in Trypetheliaceae. Similarly, maximum predicted grid values are much lower for Trypetheliaceae (little over 200 species) than for Graphidaceae (close to 600 species per grid; Lücking et al. 2014a).

As in the prediction for Graphidaceae, the individual grid estimates are not to be considered accurate in this case, since the linear correlation applies a smoothing effect on the model (Lücking et al. 2014a). However, since some grids will be overestimated, others will result in underestimations and consequently the global prediction will be unaffected as these errors cancel each other out. Nevertheless, separate consideration is required when looking at individual grids. Apart from the macroecological parameters employed in our model, other parameters can explain grid species richness, especially the evolutionary history of the area in question. This is especially the case for the Indian subcontinent, which acted as a 'biotic ferry' (McKenna 1973; Scotese 2001; Conti et al. 2002; Hedges 2003) for this region, as species richness appears to be underestimated when using environmental parameters alone, as is the case for Graphidaceae (Lücking et al. 2014a). However, this also implies that our approach is conservative and that global species richness might be even higher than predicted here.

We observed two marked differences when applying this predictive approach to the families Graphidaceae and Trypetheliaceae. First, Trypetheliaceae have a higher proportional diversity of unique taxa than Graphidaceae in biomes outside the rainforest division. For example, species of Polymeridium are rare in rainforest areas but very diverse in seasonal dry forest such as the Caatinga (Aptroot $e t$ al. 2013a). Other Trypetheliaceae are rich in savannah vegetation, where they often form unique communities (Komposch \& Hafellner 2003). The understudied Brazilian Restinga biome also seems to be a potential source of unique species in this family. Trypetheliaceae also show a marked bias in area-based diversity towards the Neotropics, a pattern not observed in Graphidaceae, which are equally diverse in well-preserved rainforest biomes across the tropics, specifically in the Neotropics and tropical Asia (Lücking et al. 2014a). The reason for this bias is unknown, but it could be related to the unique diversity of the family in biomes outside rainforests, since palaeoclimatic fluctuations have led to frequent changes in the mosaic-like distribution of rainforest and savannah-like vegetation, especially in South America (Van der Hammen 1974; Meave \& Kellmann 1994; Pennington et al. 2000; Bonaccorso et al. 2006; Flenley 2013). Further study is required to validate our assumption of species richness being generally twice as high in the Neotropics compared to the Palaeotropics, as it is based on limited results from four presumably well-sampled grids. However, further data should not affect the prediction of global species richness but might give more reliable results for individual grids.

The predicted diversity hotspot analysis suggests that most of the undiscovered species richness is to be expected in the Neotropics, particularly the Amazon region and central and southern Brazil. Recent studies in western Amazonia (Rondônia) and Bolivia have indeed revealed an extraordinary diversity of species (Aptroot \& Cáceres 2016; Flakus et al. 2016; Lücking et al. 2016a). Part of this also stems from a much more refined species concept, which suggests that morphological features of thalli and ascomata are usually species-specific and not just the result of assumed infraspecific variation (Nelsen et al. 2014; Lücking et al. 
$2016 b$ ). Since the lichen biodiversity of the lowland rainforests of tropical Africa has been poorly studied, there may be many species still to be discovered. In contrast, Indonesia is not expected to harbour larger numbers of unknown species as many of them have already been described from this area in historical treatments and have now been resurrected as part of a global revision of the family (Aptroot \& Lücking 2016). Very few historical studies for the family exist from the Neotropics and particularly the Amazon region, which makes discoveries of new species more likely.

This study was partially funded by NSF-DEB 0715660 , "Neotropical Epiphytic Microlichens-An Innovative Inventory of a Highly Diverse yet Little Known Group of Symbiotic Organisms" to The Field Museum (PI Robert Lücking). The CNPq (Conselho Nacional de Desenvolvimento Científico e Tecnológico) is thanked for a research grant and field trip funding (Processos 311706/ 2012-6 and CNPq-Sisbiota Processo 563342/2010-2) to MESC.

\section{SUPPLEMENTARY MATERIAL}

For supplementary material accompanying this paper visit http://dx.doi.org/10.1017/S0024282916000463

\section{REFERENCES}

Aptroot, A. (1991) A monograph of the Pyrenulaceae (excluding Anthracothecium and Pyrenula) and the Requienellaceae, with notes on the Pleomassariaceae, the Trypetheliaceae and Mycomicrothelia (lichenized and non-lichenized Ascomycetes). Bibliotheca Lichenologica 44: 1-178.

Aptroot, A. (1997) Lichen biodiversity in Papua New Guinea, with the report of 173 species on one tree. Bibliotheca Lichenologica 68: 203-213.

Aptroot, A. (2009a) Trypetheliaceae. In Flora of Australia, Volume 57. Lichens 5 (P. M. McCarthy, ed.): 534-552. Canberra and Melbourne: ABRS and CSIRO Publishing.

Aptroot, A. (2009b) Diversity and endemism in the pyrenocarpous lichen families Pyrenulaceae and Trypetheliaceae in the Malesian flora region. Blumea 54: 145-147.

Aptroot, A. \& Cáceres, M. E. S. (2016) New Trypetheliaceae from the Amazon basin in Rondonia (Brazil), the centre of diversity of the genus Astrothelium. Lichenologist 48: 693-712.

Aptroot, A. \& Ferraro, L. I. (2000) A new species of Polymeridium (Trypetheliaceae) non-lichenized ascomycetes from the Macrosistema Iberá, Corrientes, Argentina. Bonplandia 10: 139-141.
Aptroot, A. \& Lücking, R. (2016) A revisionary synopsis of the Trypetheliaceae (Ascomycota: Trypetheliales). Lichenologist 48: 763-982.

Aptroot, A., Lücking, R., Sipman, H. J. M., Umaña, L. \& Chaves, J. L. (2008) Pyrenocarpous lichens with bitunicate asci: a first assessment of the lichen biodiversity inventory of Costa Rica. Bibliotheca Lichenologica 97: 1-162.

Aptroot, A., Menezes, A. A., de Lima, E. L., Xavier-Leite, A. B. \& Cáceres, M. E. S. (2013a) New species of Polymeridium from Brazil expand the range of known morphological variation within the genus. Lichenologist 45: 545-552.

Aptroot, A., Nelsen, M. P. \& Parnmen, S. (2013b) Marcelaria, a new genus for the Laurera purpurina group in the Trypetheliaceae (Ascomycota: Dothideomycetes). Glalia 5: 1-15.

Bailey, R. G. (1989) Explanatory supplement to ecoregions map of the continents. Environmental Conservation 16: 307-309.

Bailey, R. G. \& Hogg, H. C. (1986) A world ecoregions map for resource reporting. Environmental Conservation 13: $195-202$.

Biedinger, N. \& Fischer, E. (1996) Epiphytic vegetation and ecology in central African forests (Rwanda, Zaïre). Ecotropica 2: 121-142.

Bonaccorso, E., Koch, I. \& Peterson, A. T. (2006) Pleistocene fragmentation of Amazon species ranges. Diversity and Distributions 12: 157-164.

Cáceres, M. E. S., Lücking, R. \& Rambold, G. (2007) Phorophyte specificity and environmental parameters versus stochasticity as determinants for species composition of corticolous lichen communities in the Atlantic rain forest of northeastern Brazil. Mycological Progress 6: 117-136.

Cáceres, M. E. S., Lücking, R. \& Rambold, G. (2008) Corticolous microlichens in northeastern Brazil: habitat differentiation between coastal Mata Atlântica, Caatinga and Brejos de Altitude. Bryologist 111: 98-117.

Chao, A. (1984) Non-parametric estimation of the number of classes in a population. Scandinavian Fournal of Statistics 11: 265-270.

Chao, A. (1987) Estimating the population size for capture-recapture data with unequal catchability. Biometrics 43: 783-791.

Conti, E., Eriksson, T., Schönenberger, J., Sytsma, K. T. \& Baum, D. A. (2002) Early Tertiary out-of-India dispersal of Crypteroniaceae: evidence from the chloroplast and nuclear genomes. Evolution 56: 1931-1942.

Córdova-Chávez, O., Aptroot, A., Castillo-Camposa, G., Cáceres, M. E. S. \& Pérez-Pérez, R. E. (2014) Three new lichen species from cloud forest in Veracuz, Mexico. Cryptogamie, Mycologie 35: 157-162.

Cornelissen, J. H. C. \& ter Steege, H. (1989) Distribution and ecology of epiphytic bryophytes and lichens in dry evergreen forest of Guyana. Fournal of Tropical Ecology 5: 131-150.

Del Prado, R., Schmitt, I., Kautz, S., Palice, Z., Lücking, R. \& Lumbsch, H. T. (2006) Molecular data place Trypetheliaceae in Dothideomycetes. Mycological Research 110: 511-520. 
Dodge, C. W. (1953) Some lichens from tropical Africa. Annals of the Missouri Botanical Garden 40: 271-401.

Flakus, A., Kukwa, M. \& Aptroot, A. (2016) Trypetheliaceae of Bolivia: an updated checklist with descriptions of twenty-four new species. Lichenologist 48: 661-692.

Flenley, J. R. (2013) The Equatorial Rain Forest: a Geological History. Amsterdam: Elsevier.

Harris, R. C. (1984) The family Trypetheliaceae (Loculoascomycetes: lichenized Melanommatales) in Amazonian Brazil. Supplement Acta Amazonica 14: $55-80$.

Harris, R. C. (1991) A revision of Polymeridium (Müll. Arg.) R. C. Harris (Trypetheliaceae). Boletim do Museu Paraense Emilio Goeldi, Série Botânica 7: 619-644.

Harris, R. C. (1998) A preliminary revision of Pseudopyrenula Müll. Arg. (lichenized Ascomycetes, Trypetheliaceae) with a redisposition of the names previously assigned to the genus. In Lichenographia Thomsoniana: North American Lichenology in Honor of fohn W. Thomson (M. G. Glenn, R. C. Harris, R. Dirig \& M. S. Cole, eds): 133-148. Ithaca, New York: Mycotaxon Ltd.

Hedges, S. B. (2003) The coelacanth of frogs. Nature 425: 669-670.

Holz, I. \& Gradstein, S. R. (2005) Cryptogamic epiphytes in primary and recovering upper montane oak forests of Costa Rica - species richness, community composition and ecology. Plant Ecology 178: 89-109.

Hyde, K. D., Jones, E. B. G, Liu, J.-K., Ariyawansha, H., Boehm, E., Boonmee, S., Braun, U., Chomnunti, P., Crous, P. W., Dai, D. et al. (2013) Families of Dothideomycetes. Fungal Diversity 63: 1-313.

Komposch, H. \& Hafellner, J. (1999) List of lichenized fungi so far observed in the tropical lowland rain forest plot Surumoni (Venezuela, Estado Amazonas). Fritschiana 19: 1-10.

Komposch, H. \& Hafellner, J. (2000) Diversity and vertical distribution of lichens in a Venezuelan tropical lowland rain forest. Selbyana 21: 11-24.

Komposch, H. \& Hafellner, J. (2002) Life form diversity of lichenized fungi in an Amazon lowland rain forest. Bibliotheca Lichenologica 82: 311-326.

Komposch, H. \& Hafellner, J. (2003) Species composition of lichen dominated corticolous communities: a lowland rain forest canopy compared to an adjacent shrubland in Venezuela. Bibliotheca Lichenologica 86: 351-367.

Komposch, H., Aptroot, A. \& Hafellner, J. (2002) New species of lichenized and non-lichenized ascomycetes from canopy in southern Venezuela. Lichenologist 34: 223-235.

Lakatos, M., Rascher, U. \& Büdel, B. (2006) Functional characteristics of corticolous lichens in the understory of a tropical lowland rain forest. New Phytologist 172: 679-695.

Letrouit-Galinou, M. A. (1957) Revision monographique du genre Laurera (lichenes, Trypéthéliacées). Revue Bryologique et Lichénologique 26: 207-264.

Letrouit-Galinou, M. A. (1958) Revision monographique du genre Laurera (lichenes, Trypéthéliacées). Supplement I. Revue Bryologique et Lichénologique 27: $66-73$.
Lima, E. L., Maia, L. C., Aptroot, A. \& Cáceres, M. E. S. (2013) New lichen species from Vale do Catimbau, Pernambuco, Brazil. Bryologist 116: 327-329.

Lücking, R. (2001) Lichens on leaves in tropical rainforests: life in a permanently ephemerous environment. Dissertationes Botanicae 346: 41-77.

Lücking, R. (2008) Foliicolous lichenized fungi. Flora Neotropica Monograph 103: 1-866.

Lücking, R. \& Matzer, M. (2001) High foliicolous lichen alpha-diversity on individual leaves in Costa Rica and Amazonian Ecuador. Biodiversity and Conservation 10: 2139-2152.

Lücking, R., Sipman, H. J. M., Umaña, L., Chaves, J. L. \& Lumbsch, H. T. (2007) Aptrootia (Dothideomycetes: Trypetheliaceae), a new genus of pyrenocarpous lichens for Thelenella terricola. Lichenologist 39: 187-193.

Lücking, R., Seavey, F., Common, R. S., Beeching, S. Q., Breuss, O., Buck, W. R., Crane, L., Hodges, M., Hodkinson, B. P., Lay, E. et al. (2011) The lichens of Fakahatchee Strand Preserve State Park, Florida: proceedings from the 18th Tuckerman Workshop. Bulletin of the Florida Museum of Natural History, Biological Sciences 49: 127-186.

Lücking, R., Johnston, M. K., Aptroot, A., Kraichak, E., Lendemer, J. C., Boonpragob, K., Cáceres, M. E. S., Ertz, D., Ferraro, L. I., Jia, Z.-F. et al. (2014a) One hundred and seventy-five new species of Graphidaceae: closing the gap or a drop in the bucket? Phytotaxa 189: 7-38.

Lücking, R., Dal-Forno, M., Sikaroodi, M., Gillevet, P. M., Bungartz, F., Moncada, B., Yánez-Ayabaca, A., Chaves, J. L., Coca, L. F. \& Lawrey, J. D. (2014b) A single macrolichen constitutes hundreds of unrecognized species. Proceedings of the National Academy of Sciences of the United States of America 111: 11091-11096.

Lücking, R., Nelsen, M. P., Aptroot, A., Benatti, M. N., Binh, N. Q., Gueidan, C., Gutiérrez, M. C., Jungbluth, P., Lumbsch, H. T., Marcelli, M. P. et al. (2016a) A pot-pourri of new species of Trypetheliaceae resulting from molecular phylogenetic studies. Lichenologist 48: 639-660.

Lücking, R., Nelsen, M. P., Aptroot, A., Barillas de Klee, R., Bawingan, P. A., Benatti, M. N., Binh, N. Q., Bungartz, F., Cáceres, M. E. S., Canêz, L. S. et al. (2016b) A phylogenetic framework for reassessing generic concepts and species delimitation in the lichenized family Trypetheliaceae (Ascomycota: Dothideomycetes). Lichenologist 48: 739-762.

Makhija, U. \& Patwardhan, P. G. (1988) The lichen genus Laurera (family Trypetheliaceae) in India. Mycotaxon 31: 565-590.

Makhija, U. \& Patwardhan, P. G. (1993) A contribution to our knowledge of the lichen genus Trypethelium (family Trypetheliaceae). Fournal of the Hattori Botanical Laboratory 73: 183-219.

Malme, G. O. A. (1924) Die Flechten der ersten Regnellschen Expedition. 2. Astrotheliaceae, Paratheliaceae und Trypetheliaceae. Arkiv för Botanik 19 (1): 1-34. 
Marcelli, M. P. (1992) Ecologia Liquênica nos Manguezais do Sul-Sudeste. Bibliotheca Lichenologica 47: 1-310.

McCarthy, P. M. (1995) Laurera papillosa (Trypetheliaceae), a remarkable new lichen from Papua New Guinea. Lichenologist 27: 310-314.

McCarthy, P. M. \& Kantvilas, G. (1993) Laurera robusta (Trypetheliaceae), a new alpine lichen from Tasmania. Lichenologist 25: 51-55.

McKenna, M. C. C. (1973) Sweepstakes, filters, corridors, Noah's Arks, and beached Viking funeral ships in palaeogeography. In Implications of Continental Drift to the Earth Sciences (D. H. Tarling \& S. K. Runcorn, eds): 291-304. London: Academic Press.

Meave, J. \& Kellman, M. (1994) Maintenance of rain forest diversity in riparian forests of tropical savannas: implications for species conservation during Pleistocene drought. Fournal of Biogeography 21: 121-135.

Montfoort, D. \& Ek, R. (1990) Vertical Distribution and Ecology of Epiphytic Bryophytes and Lichens in a Lowland Rain Forest in French Guiana. Utrecht: Institute of Systematic Botany.

Müller, J. (1888) Pyrenocarpeae Féeanae in Féei Essai (1829) et Supplément (1837) editae e novo studio speciminum originalium expositae et in novam dispositionem ordinatae. Memoires de la Société de Physique et d'histoire Naturelle de Genève 30: 1-45.

Nelsen, M. P., Lücking, R., Grube, M., Mbatchou, J. S., Muggia, L., Rivas Plata, E. \& Lumbsch, H. T. (2009) Unravelling the phylogenetic relationships of lichenised fungi in Dothideomyceta. Studies in Mycology 64: 135-144.

Nelsen, M. P., Lücking, R., Mbatchou, J. S., Andrew, C. J., Spielmann, A. A. \& Lumbsch, H. T. (2011) New insights into relationships of lichen-forming Dothideomycetes. Fungal Diversity 51: 155-162.

Nelsen, M. P., Lücking, R., Aptroot, A., Andrew, C. J., Cáceres, M. E. S., Rivas Plata, E., Gueidan, C., da Silva Canêz, L., Knight, A., Ludwig, L. R. et al. (2014) Elucidating phylogenetic relationships and genus-level classification within the fungal family Trypetheliaceae (Dothideomycetes: Ascomycota). Taxon 63: 974-992.
Nöske, N. M. \& Sipman, H. J. M. (2004) Cryptogams of the Reserva Biológica San Francisco (Province Zamora-Chinchipe, Southern Ecuador) II. Lichens. Cryptogamie, Mycologie 25: 91-100.

Pennington, R. T., Prado, D. E. \& Pendry, C. A. (2000) Neotropical seasonally dry forests and Quaternary vegetation changes. Fournal of Biogeography 27: 261-273.

Rivas Plata, E., Lücking, R. \& Lumbsch, H. T. (2008) When family matters: an analysis of Thelotremataceae (lichenized Ascomycota: Ostropales) as bioindicators of ecological continuity in tropical forests. Biodiversity and Conservation 17: 1319-1351.

Rout, J., Bichitra Singha, A. \& Upreti, D. K. (2012) Lichen flora on betel nut (Areca catechu) palm tree from a pristine habitat in southern Assam, India. Vegetos 25: 198-201.

Scotese, C. R. (2001) Atlas of Earth History. Arlington: PALAEOMAP Project.

Singh, K. P. \& Sinha, G. P. (2010) Indian Lichens. An Annotated Checklist. Kolkata: Botanical Survey of India, Ministry of Environment and Forests.

Sipman, H. J. M. \& Harris, R. C. (1989) Lichens. In Tropical Rain Forest Ecosystems (H. Lieth \& M. J. A. Werger, eds): 303-309. Amsterdam: Elsevier.

Trevisan, V. (1861) Synopsis generum Trypethelinarum. Flora 44: 17-26.

Van der Hammen, T. (1974) The Pleistocene changes of vegetation and climate in tropical South America. Fournal of Biogeography 1: 3-26.

Weerakoon, G. \& Aptroot, A. (2014) Over 200 new lichen records from Sri Lanka, with three new species to science. Cryptogamie, Mycologie 35: 51-62.

Whittaker, R. H. (1960) Vegetation of the Siskiyou Mountains, Oregon and California. Ecological Monographs 30: 279-338.

Wolf, J. H. D. (1993) Diversity patterns and biomass of epiphytic bryophytes and lichens along an altitudinal gradient in the northern Andes. Annals of the Missouri Botanical Garden 80: 928-960. 